\title{
A simple risk-based strategy for hepatitis $C$ virus screening among incarcerated people in a low- to middle-income setting
}

\author{
Sanam Hariri ${ }^{1 \dagger}$, Maryam Sharafkhah ${ }^{2 \dagger}$, Maryam Alavi ${ }^{3}$, Gholamreza Roshandel $^{4}$, Abdolreza Fazel ${ }^{5}$, Taghi Amiriani ${ }^{4}$,
} Nazgol Motamed-Gorji ${ }^{1}$, Abolfazl Bazazan ${ }^{6}$, Shahin Merat ${ }^{1}$, Hossein Poustchi ${ }^{*}$ (D) and Reza Malekzadeh

\begin{abstract}
Background: Hepatitis C virus ( $\mathrm{HCV}$ ) is among the highest priority diseases in custodial settings; however, the diagnosis remains suboptimal among people in custody. This study aimed to validate a short survey for identifying people with HCV infection in a provincial prison in Iran.

Methods: Between July and December 2018, residents and newly admitted inmates of Gorgan central prison completed a questionnaire, including data on the history of HCV testing, drug use, injecting drug use, sharing injecting equipment, and imprisonment. Participants received rapid HCV antibody testing, followed by venipuncture for RNA testing (antibody-positive only). Each enrollment question (yes/no) was compared with the testing results (positive/negative).

Results: Overall, 1892 people completed the questionnaire, including 621 (34\%) who were currently on opioid agonist therapy (OAT); $30 \%$ of participants had been tested for HCV previously. About $71 \%$ had a history of drug use, of whom 13\% had ever injected drugs; $52 \%$ had ever shared injecting equipment. The prevalence of HCV antibody and RNA was 6.9\% $(n=130)$ and $4.8 \%(n=90)$, respectively. The antibody prevalence was higher among people on OAT compared to those with no history of OAT (11.4\% vs. 4.0\%). History of drug use was the most accurate predictor of having a positive HCV antibody (sensitivity: 95.2\%, negative predictive value: 98.9\%) and RNA testing (sensitivity: $96.7 \%$, negative predictive value: $99.5 \%$ ). The sensitivity of the drug use question was lowest among people with no OAT history and new inmates (87\% and $89 \%$, respectively). Among all participants, sensitivity and negative predictive value of the other questions were low and ranged from 34 to $54 \%$ and 94 to $97 \%$, respectively.
\end{abstract}

Conclusions: In resource-limited settings, HCV screening based on having a history of drug use could replace universal screening in prisons to reduce costs. Developing tailored screening strategies together with further cost studies are crucial to address the current HCV epidemic in low- to middle-income countries.

Keywords: Hepatitis C virus (HCV), Screening, Micro-elimination, Prison healthcare, Harm reduction, Drug use, Opioid agonist therapy, Low- and middle-income countries

\footnotetext{
* Correspondence: h.poustchi@gmail.com

†Sanam Hariri and Maryam Sharafkhah contributed equally to this work. 'Liver and Pancreatobiliary Diseases Research Center, Digestive Diseases Research Institute, Shariati Hospital, Tehran University of Medical Sciences, Tehran, Iran

Full list of author information is available at the end of the article
}

(c) The Author(s). 2020 Open Access This article is licensed under a Creative Commons Attribution 4.0 International License, which permits use, sharing, adaptation, distribution and reproduction in any medium or format, as long as you give appropriate credit to the original author(s) and the source, provide a link to the Creative Commons licence, and indicate if changes were made. The images or other third party material in this article are included in the article's Creative Commons licence, unless indicated otherwise in a credit line to the material. If material is not included in the article's Creative Commons licence and your intended use is not permitted by statutory regulation or exceeds the permitted use, you will need to obtain permission directly from the copyright holder. To view a copy of this licence, visit http://creativecommons.org/licenses/by/4.0/. The Creative Commons Public Domain Dedication waiver (http://creativecommons.org/publicdomain/zero/1.0/) applies to the data made available in this article, unless otherwise stated in a credit line to the data. 


\section{Background}

Hepatitis $\mathrm{C}$ virus (HCV) infection is a global health concern with a rising disease burden [1]. The introduction of highly effective therapies has revolutionized the treatment landscape, particularly in low- and middle-income countries (LMIC) [2]. However, HCV diagnosis remains suboptimal in many regions, including Iran [3]. To achieve the World Health Organization's (WHO) target of HCV elimination as a public health issue by 2030, we need effective screening and diagnosis strategies among high-risk groups, including people in custody $[1,4]$.

In Iran, the prevalence of $\mathrm{HCV}$ infection among the general population is estimated at $0.6 \%$ [5]. However, prevalence is approximately $45 \%$ among people who inject drugs (PWID), 28\% among people in prison, and $53 \%$ among prisoners with a history of drug injection [6-9]. Generic direct-acting antivirals (DAA) with more than $95 \%$ cure rates in 12 weeks of therapy have been formulated in Iran and are available at low prices [1012]. Despite the potential for treatment with shortduration regimens, HCV diagnosis and treatment uptake have been low among people in custody [4]. In the last decade, in Iranian prisons, harm reduction initiatives, including opioid agonist therapy (OAT), have been widely implemented [13, 14]. Further, the diagnosis and treatment of infectious diseases, including TB and HIV, have significantly increased $[15,16]$. The existing infrastructure of harm reduction and primary health care could be utilized to increase HCV diagnosis and linkage to care as well, given the development of low-cost methods for active case finding [17].

In high-income countries, risk-based surveys have been used to increase HCV diagnosis in custodial settings $[18,19]$. However, there is no information on previous risk-based screening for infectious diseases in LMIC. Therefore, the effectiveness of this method for enhancing the HCV diagnosis among marginalized populations is questioned. In a large provincial prison with no HCV programs, we aimed to validate a 1-min survey vs. HCV antibody and RNA testing for the identification of people with infection.

\section{Methods}

\section{Study population and design}

This study was a non-randomized trial, evaluating the reliability of a self-reported questionnaire in predicting HCV antibody and RNA testing results. Enrollment occurred between July and December 2018. The study site was Gorgan central prison, located in Northern Iran. All residents and newly admitted inmates were eligible to participate in the study, given they were at least 18 years old and had provided written consent. Participation was voluntary, and participants could withdraw their consent at any time. The Institutional Review Board of Tehran University of Medical Sciences approved the research protocol.

\section{Study site}

Gorgan central prison is located in Gorgan city, Golestan province, Northern Iran. This prison has an approximate inmate population of 2000 and consists of eight wards: public, remands, serious crimes, female, juvenile, solitary confinement, and two wards for people receiving OAT. The prison had a general practitioner and two nurses providing healthcare services, including harm reduction activities and HIV testing. However, there was no HCV program available in this prison.

\section{Study procedures}

Before enrollment, prison health officials invited all inmates to provide education on $\mathrm{HCV}$ disease and its complications, routes of transmission, and safe injection techniques. Further, an illustrated booklet was given to participants, containing useful information about $\mathrm{HCV}$ infection and liver health. Residents and newly admitted inmates completed a short questionnaire, including information on the history of $\mathrm{HCV}$ testing, drug use, injecting drug use, sharing injecting equipment, and imprisonment (Table 1).

All participants received on-site rapid HCV antibody testing, using a blood specimen from a fingerstick; posttest counseling was provided. Among participants with a positive $\mathrm{HCV}$ antibody test, the prison nurses were available to collect venipuncture blood samples weekly. These participants were invited to attend the prison clinic once a week to provide a sample for HCV RNA testing and other routine clinical care, including HIV and hepatitis B virus serology, liver function tests, and complete blood count.

Participants with positive HCV RNA received treatment with a locally manufactured combination of 400 mg Sofosbuvir and $60 \mathrm{mg}$ Daclatasvir (Sovodak ${ }^{\oplus}$ ). AST to Platelet Ratio Index (APRI) was used for liver disease assessment. The duration of antiviral therapy ranged from 12 to 24 weeks for people without cirrhosis (APRI < 1 ) and those with cirrhosis (APRI $>1$ ), respectively. We delivered all required education for treatment and monitoring to the prison physician. Patients released during the study were referred to the local health network for follow-up. All study activities were provided to participants free of charge.

\section{Study outcomes}

The primary outcome of this study was to investigate the role of a 1-min questionnaire as a risk-based strategy in HCV screening. The other outcome was to evaluate the prevalence of $\mathrm{HCV}$ antibody and HCV RNA among 
Table 1 Screening questionnaire of hepatitis C risk factors in the Gorgan prison study

\begin{tabular}{|c|c|}
\hline Question & Answer \\
\hline 1. Have you ever been tested for hepatitis $C$ ? & $\begin{array}{l}\text { A. Yes, I have been tested. Currently, I do not have hepatitis C } \\
\text { B. Yes, I have been tested. Currently, I have hepatitis C. } \\
\text { C. Yes, I have been tested. Currently, I do not know whether I } \\
\text { have hepatitis C or not. } \\
\text { D. No, I have not been tested. } \\
\text { E. I do not know. }\end{array}$ \\
\hline 2. Do you have a history of drug use, ever? & $\begin{array}{l}\text { A. Yes } \\
\text { B. No }\end{array}$ \\
\hline 3. Do you have a history of injection drug use, ever? & $\begin{array}{l}\text { A. Yes } \\
\text { B. No }\end{array}$ \\
\hline $\begin{array}{l}\text { 4. Do you have a history of sharing injection equipment, ever? } \\
\text { (Including needle, syringe, spoon, solvent, filter or water) }\end{array}$ & $\begin{array}{l}\text { A. Yes } \\
\text { B. No }\end{array}$ \\
\hline $\begin{array}{l}\text { 5. Do you have a history of prior imprisonment? } \\
\text { (Only newly admitted inmates) }\end{array}$ & $\begin{array}{l}\text { A. Yes } \\
\text { B. No }\end{array}$ \\
\hline
\end{tabular}

all participants and people with a positive antibody test, respectively.

\section{Statistical analysis}

Data are presented as median (interquartile range (IQR)) or frequency and percentage, as appropriate. Each enrollment questionnaire (yes/no) was compared with the results of the HCV antibody testing (positive/negative) and RNA testing (positive/negative). The RNA testing results were evaluated among participants with available information. The enrollment question about previous $\mathrm{HCV}$ testing had multiple answers; for comparison, we combined the first three answers (Table 1). Sensitivity, specificity, positive predictive value (PPV), and negative predictive value (NPV) of each question were estimated.

\section{Results}

\section{Study population}

Overall, 1892 participants were enrolled, including 1482 residents with a median age of 35 years (IQR 29-41) and 410 newly admitted inmates. The majority were male (96\%), did not have higher education (89\%), had a monthly income at minimum wage or below (77\%), and 34\% were currently receiving OAT services. Residents had lower education and monthly income, compared to newly admitted inmates. Similarly, people who were receiving OAT had lower education and monthly income than those who were not currently on OAT (Tables 2 and 3).

Among all participants, $71 \%(n=1341)$ had a history of drug use, of whom 13\% $(n=174)$ had a history of injecting drug use; $52 \%(n=91)$ of people with injecting drug use had ever shared injecting equipment. The history of drug use and injecting among residents was slightly higher than new inmates (72\% vs. $69 \%$, and $14 \%$ vs. $10 \%)$. People who were currently receiving OAT had a higher prevalence of drug use, injecting drug use, and sharing injecting equipment, compared to those who were not currently on OAT ( $92 \%$ vs. $62 \% ; 18 \%$ vs. $10 \%$, and $57 \%$ vs. $48 \%$, respectively) (Table 3 ).

\section{History of HCV testing}

Overall, 30\% (558/1887) of participants had a history of HCV testing, including 36\% (527/1478) and 8\% (31/409) among residents and newly admitted inmates, respectively. Among people who had a history of HCV testing, only $41 \%$ (229/558) were aware of their test results. Having a history of testing was reported in $33 \%$ and $28 \%$ of participants on OAT and those who were not currently on OAT, respectively (Tables 2 and 3 ).

\section{Prevalence of HCV antibody and RNA}

$\mathrm{HCV}$ antibody was detected in $6.9 \%(n=130)$ of all participants, including $7.5 \%(n=111)$ of residents and $4.6 \%$ $(n=19)$ of newly admitted inmates. Among residents, the prevalence of $\mathrm{HCV}$ antibody was highest in OAT wards with $13.2 \%(80 / 607)$, followed by remands $3.5 \%$ $(8 / 230)$ and public $3.5 \%(11 / 317)$. The prevalence of HCV RNA among residents was $5.7 \%(n=84)$. Out of 19 newly admitted inmates with a positive antibody in the remand ward, 11 were released before the RNA testing; among those who received venipuncture, the HCV viremic rate was $75 \%$ (6 of 8 ). For participants who were currently on OAT and those who were not receiving OAT, the prevalence of antibody was $11.4 \%(71 / 621)$ and $4.6 \%$ (55/1190); HCV RNA was detected in $8.7 \%$ (54/619) and 2.9\% (34/1182), respectively (Table 4).

\section{Concordance of the risk-based questionnaire and antibody testing}

The drug use question was the most accurate predictor of having a positive $\mathrm{HCV}$ antibody test (sensitivity: 95.4\%, negative predictive value: $98.9 \%$ ), with a higher sensitivity in residents compared to new inmates $(96 \%$ vs. $89 \%$ ). The sensitivity of the drug use question among 
Table 2 Frequency of risk behaviors and HCV screening among Gorgan prison residents and new inmates, $n=1892$

\begin{tabular}{|c|c|c|c|}
\hline & Residents & New inmates & All \\
\hline Characteristics, n (\%) & $n=1482$ & $n=410$ & $n=1892$ \\
\hline Age, median (IQR) & $35(29-41)$ & - & $35(29-41)$ \\
\hline \multicolumn{4}{|l|}{ Sex } \\
\hline Male & $1414(95.4 \%)$ & $410(100 \%)$ & $1824(96.4 \%)$ \\
\hline Female & $68(4.6 \%)$ & - & $68(3.6 \%)$ \\
\hline \multicolumn{4}{|l|}{ Highest educational level } \\
\hline Did not go to school & $143(9.7 \%)$ & $25(6.1 \%)$ & $168(8.9 \%)$ \\
\hline Did not finish high school & $911(61.5 \%)$ & $161(39.3 \%)$ & $1072(56.7 \%)$ \\
\hline Finished high school & $268(18.1 \%)$ & $172(42.0 \%)$ & $440(23.3 \%)$ \\
\hline Higher education & $112(7.6 \%)$ & $47(11.5 \%)$ & $159(8.4 \%)$ \\
\hline Missing & 48 (3.2\%) & $5(1.2 \%)$ & $53(2.8 \%)$ \\
\hline \multicolumn{4}{|l|}{ Monthly income } \\
\hline Minimum wage or below & 1194 (80.6\%) & $271(66.1 \%)$ & $1465(77.4 \%)$ \\
\hline Living wage & $185(12.5 \%)$ & $104(25.4 \%)$ & $289(15.3 \%)$ \\
\hline Above living wage & $65(4.4 \%)$ & $25(6.1 \%)$ & $90(4.8 \%)$ \\
\hline Missing & $38(2.6 \%)$ & $10(2.4 \%)$ & $48(2.5 \%)$ \\
\hline \multicolumn{4}{|l|}{ Drug use, ever } \\
\hline No & $419(28.3 \%)$ & $128(31.2 \%)$ & $547(29.0 \%)$ \\
\hline Yes & $1059(71.5 \%)$ & $282(68.8 \%)$ & $1341(70.9 \%)$ \\
\hline \multicolumn{4}{|l|}{ Injecting drug use, ever } \\
\hline No & $910(85.9 \%)$ & $254(90.1 \%)$ & $1,164(86.8 \%)$ \\
\hline Yes & $146(13.8 \%)$ & $28(9.9 \%)$ & $174(13.0 \%)$ \\
\hline \multicolumn{4}{|l|}{ Shared injection equipment, ever } \\
\hline No & $62(42.5 \%)$ & $10(35.7 \%)$ & $72(41.4 \%)$ \\
\hline Yes & $73(50.0 \%)$ & $18(64.3 \%)$ & $91(52.3 \%)$ \\
\hline Missing & $11(7.5 \%)$ & $0(0.0 \%)$ & $11(6.3 \%)$ \\
\hline \multicolumn{4}{|l|}{ Imprisonment, ever } \\
\hline No & - & $128(31.2 \%)$ & $128(31.2 \%)$ \\
\hline Yes & - & $282(68.8 \%)$ & $282(68.8 \%)$ \\
\hline \multicolumn{4}{|l|}{ HCV screening, ever } \\
\hline No & $874(59.0 \%)$ & $342(83.4 \%)$ & $1216(64.3 \%)$ \\
\hline Do not know & $77(5.2 \%)$ & $36(8.8 \%)$ & $113(6.0 \%)$ \\
\hline Yes, currently have HCV & $21(1.4 \%)$ & $3(0.7 \%)$ & $24(1.3 \%)$ \\
\hline Yes, currently do not have HCV & $191(12.9 \%)$ & $14(3.4 \%)$ & $205(10.8 \%)$ \\
\hline Yes, do not know the current status & $315(21.3 \%)$ & $14(3.4 \%)$ & $329(17.4 \%)$ \\
\hline
\end{tabular}

$I Q R$ interquartile range

participants who were currently receiving OAT and those with and without a history of OAT were $100 \%$, $94 \%$, and $87 \%$, respectively (Tables 5 and 6).

The sensitivity and negative predictive value of the other questions were low and ranged from 34 to $54 \%$ and 94 to $97 \%$ among all participants, respectively. Having a history of injection and sharing injection equipment was more sensitive for case finding among residents than new inmates (sensitivity: $58 \%$ vs. $26 \%$ and $37 \%$ vs. $16 \%$, respectively), and people on OAT than those with no such history (sensitivity: 65\% vs. $39 \%$ and $45 \%$ vs. $17 \%$, respectively). The question about previous HCV testing did not find any new inmates with positive antibody but was $49 \%$ sensitive for case finding among residents. Among people on $\mathrm{OAT}$, and those participants with and without a history of OAT, testing history was $45 \%, 25 \%$, and $47 \%$ sensitive, respectively. 
Table 3 Frequency of risk behaviors and HCV screening categorized by history of opioid agonist therapy (OAT)

\begin{tabular}{|c|c|c|c|}
\hline Characteristics, n (\%) & $\begin{array}{l}\text { People on OAT } \\
n=621\end{array}$ & $\begin{array}{l}\text { People with a history of OAT } \\
n=241\end{array}$ & $\begin{array}{l}\text { People with no history of OAT } \\
n=949\end{array}$ \\
\hline \multicolumn{4}{|l|}{ Sex } \\
\hline Male & $602(96.9 \%)$ & $237(98.3 \%)$ & 909 (95.3\%) \\
\hline Female & $19(3.1 \%)$ & $4(1.7 \%)$ & $45(4.7 \%)$ \\
\hline \multicolumn{4}{|l|}{ Highest educational level } \\
\hline Did not go to school & $62(10.0 \%)$ & $12(5.0 \%)$ & $86(9.1 \%)$ \\
\hline Did not finish high school & $356(57.3 \%)$ & $148(61.4 \%)$ & $521(54.9 \%)$ \\
\hline Finished high school & $137(22.1 \%)$ & $55(22.8 \%)$ & $238(25.1 \%)$ \\
\hline Higher education & $47(7.6 \%)$ & $18(7.5 \%)$ & $82(8.6 \%)$ \\
\hline Missing & $19(3.1 \%)$ & $8(3.3 \%)$ & $22(2.3 \%)$ \\
\hline \multicolumn{4}{|l|}{ Monthly income } \\
\hline Minimum wage or below & $508(81.8 \%)$ & $191(79.3 \%)$ & 709 (74.7\%) \\
\hline Living wage & $87(14.0 \%)$ & $33(13.7 \%)$ & $158(16.7 \%)$ \\
\hline Above living wage & $21(3.4 \%)$ & $9(3.7 \%)$ & $51(5.4 \%)$ \\
\hline Missing & $5(0.8 \%)$ & $8(3.3 \%)$ & $31(3.3 \%)$ \\
\hline \multicolumn{4}{|l|}{ Drug use, ever } \\
\hline No & $52(8.4 \%)$ & $66(27.4 \%)$ & $390(41.1 \%)$ \\
\hline Yes & $569(91.6 \%)$ & $174(72.2 \%)$ & $557(58.7 \%)$ \\
\hline \multicolumn{4}{|l|}{ Injecting drug use, ever } \\
\hline No & $468(82.3 \%)$ & $153(87.9 \%)$ & 506 (90.8\%) \\
\hline Yes & $100(17.6 \%)$ & $21(12.1 \%)$ & $49(8.8 \%)$ \\
\hline \multicolumn{4}{|l|}{ Shared injection equipment, ever } \\
\hline No & $35(35.0 \%)$ & $9(42.7 \%)$ & $26(53.1 \%)$ \\
\hline Yes & $57(57.0 \%)$ & $11(52.4 \%)$ & $21(42.7 \%)$ \\
\hline Missing & $8(8.0 \%)$ & $1(4.8 \%)$ & $2(4.1 \%)$ \\
\hline \multicolumn{4}{|l|}{ HCV screening, ever } \\
\hline No & $395(63.6 \%)$ & $142(58.9 \%)$ & $622(65.5 \%)$ \\
\hline Do not know & $24(3.9 \%)$ & $16(6.6 \%)$ & $71(7.5 \%)$ \\
\hline Yes, currently have HCV & $12(1.9 \%)$ & $3(1.2 \%)$ & $8(0.8 \%)$ \\
\hline Yes, currently do not have HCV & $54(8.7 \%)$ & $34(14.1 \%)$ & $107(11.3 \%)$ \\
\hline Yes, do not know the current status & $136(21.9 \%)$ & $45(18.7 \%)$ & $137(14.4 \%)$ \\
\hline
\end{tabular}

\section{Concordance of the risk-based questionnaire and RNA testing}

The drug use question was the most accurate predictor of having a positive HCV RNA results as well (sensitivity: $96.7 \%$, negative predictive value: $99.5 \%)$. The sensitivity and negative predictive value of injection and sharing questions among all inmates ranged from 59 to $63 \%$, and 97 to $73 \%$, respectively. Only 9\% (8/90) of people who had positive HCV RNA results truly answered that they currently have HCV disease. From participants who responded that they have HCV disease currently, only $33 \%(8 / 24)$ had positive RNA results,

Table 4 Prevalence of HCV antibody and HCV RNA among Gorgan prison participants

\begin{tabular}{lllllll}
\hline & Total & Residents & New inmates & People on OAT & People with a history of OAT & People with no history of OAT \\
Prevalence, $n(\%)$ & $n=1892$ & $n=1482$ & $n=410$ & $n=621$ & $n=241$ & $n=949$ \\
\hline HCV antibody & $130(6.9 \%)$ & $111(7.5 \%)$ & $19(4.6 \%)$ & $71(11.4 \%)$ & $17(7.1 \%)$ & $38(4.0 \%)$ \\
HCV RNA & $90(4.8 \%)$ & $84(5.7 \%)$ & $6(1.5 \%)$ & $54(8.7 \%)$ & $10(4.2 \%)$ & $24(2.5 \%)$ \\
\hline
\end{tabular}


Table 5 Characteristics of the questionnaire for detecting HCV antibody among Gorgan prison residents and new inmates

\begin{tabular}{|c|c|c|c|c|}
\hline History of risk behaviors & Sensitivity (\%) & Specificity (\%) & PPV (\%) & NPV (\%) \\
\hline \multicolumn{5}{|l|}{ Residents and new inmates $(n=1892)$} \\
\hline Drug use, ever & 95 & 31 & 9 & 99 \\
\hline Injecting drug use, ever & 54 & 94 & 39 & 97 \\
\hline Shared injection equipment, ever & 34 & 97 & 47 & 95 \\
\hline HCV screening, ever & 43 & 69 & 9 & 94 \\
\hline \multicolumn{5}{|l|}{ Residents $(n=1482)$} \\
\hline Drug use, ever & 96 & 30 & 10 & 99 \\
\hline Injecting drug use, ever & 58 & 94 & 43 & 97 \\
\hline Shared injection equipment, ever & 37 & 98 & 55 & 95 \\
\hline HCV screening, ever & 49 & 63 & 10 & 94 \\
\hline \multicolumn{5}{|l|}{ New inmates $(n=410)$} \\
\hline Drug use, ever & 89 & 32 & 6 & 98 \\
\hline Imprisonment, ever & 89 & 32 & 6 & 98 \\
\hline Injecting drug use, ever & 26 & 94 & 18 & 96 \\
\hline Shared injection equipment, ever & 16 & 96 & 17 & 96 \\
\hline HCV screening, ever & 0 & 91 & 0 & 95 \\
\hline
\end{tabular}

$P P V$ positive predictive value, $N P V$ negative predictive value

while among people who believed they do not have the disease, 3\% (6/205) tested positive.

\section{Discussion}

This study validates a risk-based questionnaire for the identification of people with HCV infection in Gorgan central prison, Iran. Overall, $7.5 \%$ of residents and $4.6 \%$ of newly admitted inmates had a positive HCV antibody, which was a remarkably higher prevalence than the general population
[5]. Participants who were currently receiving OAT had a higher $\mathrm{HCV}$ antibody prevalence, compared to those with no history of OAT ( $11.4 \%$ vs. $4.0 \%)$. The history of drug use was the most accurate predictor of having positive HCV antibody and RNA results, with respectively 95\% and $97 \%$ sensitivity. This outcome indicates that in low- and middle-income settings, HCV screening for people with no history of drug use could be skipped in correctional facilities.

Table 6 Characteristics of the questionnaire for detecting HCV antibody categorized by opioid agonist therapy (OAT) history

\begin{tabular}{|c|c|c|c|c|}
\hline History of risk behaviors & Sensitivity (\%) & Specificity (\%) & PPV (\%) & NPV (\%) \\
\hline \multicolumn{5}{|l|}{ People on OAT $(n=621)$} \\
\hline Drug use, ever & 100 & 9 & 12 & 100 \\
\hline Injecting drug use, ever & 65 & 90 & 46 & 95 \\
\hline Shared injection equipment, ever & 45 & 95 & 56 & 93 \\
\hline HCV screening, ever & 45 & 68 & 15 & 90 \\
\hline \multicolumn{5}{|l|}{ People with a history of OAT $(n=241)$} \\
\hline Drug use, ever & 94 & 29 & 9 & 98 \\
\hline Injecting drug use, ever & 39 & 93 & 29 & 95 \\
\hline Shared injection equipment, ever & 25 & 97 & 36 & 95 \\
\hline HCV screening, ever & 25 & 63 & 5 & 92 \\
\hline \multicolumn{5}{|c|}{ People with no history of OAT $(n=949)$} \\
\hline Drug use, ever & 87 & 42 & 6 & 99 \\
\hline Injecting drug use, ever & 39 & 96 & 29 & 98 \\
\hline Shared injection equipment, ever & 17 & 98 & 29 & 97 \\
\hline HCV screening, ever & 47 & 72 & 7 & 97 \\
\hline
\end{tabular}

PPV positive predictive value, NPV negative predictive value 
The HCV antibody prevalence in Gorgan prison was less than some previous Iranian reports, but fourteen times higher than the general population [7, 9]. Compared to a 2003 study, the prevalence of HCV antibody in this prison has decreased, which could be partly due to the implementation of harm reduction programs in recent years [20]. However, given the voluntary-based non-random design of our study, the results cannot be generalized. In Iran, $\mathrm{HCV}$ care models that are adapted for the specific needs of marginalized populations are emerging, including for people in custody; however, current interventions and harm reduction coverage are still not sufficient for breaking the cycle of transmission [21].

While the choice of a screening strategy is highly influenced by the expected prevalence and budget priorities, evidence on the different HCV screening approaches in low- and middle-income countries is scarce [18, 22]. In resource-limited settings, risked-based screening is postulated to be of value for case finding among target populations [7, 19]. However, the reliability of self-reported risk behaviors and the consistency with which the screening criteria are applied have shown to limit the early case detection ability $[19,23]$. Studies on the efficacy of a risk-based HCV strategy among marginalized populations are limited, and to date, case finding by surveys have been only done in high-income countries [18, 19]. Previous studies have shown benefits for universal screening in correctional facilities, compared to the riskbased screening, which is in contrast to our findings [18, 24]. A possible explanation could be that in Iran, no taboo exists around non-injecting drug use among the incarcerated population, which results in more reliable self-reported information [25]. To avoid loss of treatment opportunity in prisons, the diagnosis and linkage to care for this hard-to-reach population should be obtained immediately upon admission [18, 26, 27]. Therefore, tailored screening strategies should be developed to scale-up diagnosis among people in custody.

Evaluation of the HCV screening among target populations in resource-limited countries is limited [28]. In this study, only $30 \%$ of the prison population had been tested for HCV before, from whom 59\% were not aware of their test results, indicating the insufficiency of prison-based screening programs as well as poor $\mathrm{HCV}$ knowledge and post-test counseling. The history of HCV testing is similar to the previous estimates among people who use drugs in Iran (30\% vs. 28\%) [21]. However, compared to people attending substance use treatment programs in the USA, the rate of people who had never been tested for HCV in this prison was two-fold higher (69\% vs. 30\%) [29]. Besides, self-reported information regarding the previous $\mathrm{HCV}$ test results with a high rate of false positives and negatives was unreliable $(67 \%$ and
$3 \%)$, which is a common observation among prison studies [30].

The history of drug use among all participants was remarkably high and very similar to the results from a study on 6200 Iranian inmates (71\% vs. 74\%) [4]. The prevalence of drug use between residents and newly admitted inmates was almost similar (72\% vs. 69\%), which could be due to the fact that the majority of new inmates had a history of prior imprisonment (69\%). Among all inmates with a history of drug use, $9 \%$ had a positive antibody that is 18-fold higher compared to the general population of Golestan province, where the study site is located [31]. Moreover, participants who were currently receiving OAT represented a more vulnerable population for HCV infection compared to those with no history of OAT (11.4\% vs. $4.0 \%)$. These results indicate that future $\mathrm{HCV}$ screening efforts should focus on people with a history of drug use, particularly those who are attending or have a history of OAT. Comprehensive public health response to $\mathrm{HCV}$ in prisons should include tailored screening strategies and drug intervention programs such as OAT scale-up, together with assessment of health risk behaviors [21].

The history of drug use was the most sensitive question for predicting a positive HCV antibody test among all inmates (95\%); this sensitivity was lower among newly admitted inmates compared to residents (89\% vs. 96\%), highlighting the fact that new inmates are more reluctant to disclose their drug use. Despite the high sensitivity of the drug use question, the other risk factors were low sensitive for case finding: among people with a positive $\mathrm{HCV}$ antibody test, $46 \%$ and $66 \%$ did not report any history of injecting drug use and sharing, respectively. Therefore, lifetime experience of injecting drug use and sharing needles is under-reported among people in prison. The unreliability of self-reported history of injecting drug use had been reported in other studies as well, which could be due to the existing reluctance of inmates to disclose their risk behaviors and face probable punishments in custody [32]. It seems that risk-based screening could become a replacement for universal $\mathrm{HCV}$ testing provided that ongoing efforts are made to reduce stigma around drug use and injection in societies. Further, despite the extensive harm reduction efforts in the recent decade, such programs are still inadequate in Iran, as well as many other countries [33].

The main strength of this study was its novelty in developing a low-cost strategy for countries with limited resources in the battle against $\mathrm{HCV}$. However, our study had some limitations like using self-reported data, which its reliability has been questioned [19, 23]. The main limitation is that because of the high costs of HCV RNA screening for all inmates, we assumed that our antibody kit has almost $100 \%$ sensitivity for diagnosing people 
with HCV infection. Thus, having a negative antibody is considered as negative RNA testing, which may slightly change our results due to the testing bias. However, in a previous study, we have shown that the sensitivity of our rapid screening test is almost 100\% [34]. Another limitation was that among newly admitted inmates with positive antibody $(n=19), 11$ people were released before RNA testing. The venipuncture samples could not be collected daily, given limited capacity for RNA testing at the local laboratory and the lack of a fixed nurse in prison for obtaining blood samples. Participants were receiving HCV rapid testing upon admission daily, but those with a positive antibody were undergoing venipuncture after a few days, during which someone might be released. Aside from newly admitted inmates, all of the prison residents with positive antibody tests underwent venipuncture and had data available. Also, the small number of female participants limits the generalizability of this study.

\section{Conclusions}

Screening for HCV infection based on having a history of drug use could replace universal screening in correctional facilities to reduce costs. However, the history of drug injection and sharing injection equipment remain underreported. History of HCV testing is sub-optimal among inmates in Iran; therefore, effective prison-based programs are needed to scale-up HCV diagnosis and linkage to care for the people who are rarely reached by healthcare systems. Moreover, drug interventions and co-morbid health assessments should be enhanced to reduce the harms from people who cycle through custody. In resource-limited settings, tailored HCV screening strategies are crucial for pursuing elimination targets, and further cost-effectiveness analysis is needed to confirm the optimal strategies.

\section{Abbreviations}

HCV: Hepatitis C virus; OAT: Opioid agonist therapy; LMIC: Low- and middleincome countries; WHO: World Health Organization; PWID: People who inject drugs; DAA: Direct-acting antivirals; TB: Tubercle bacillus; HIV: Human immunodeficiency virus; APRI: AST to Platelet Ratio Index; PPV: Positive predictive value; NPV: Negative predictive value; IQR: Interquartile range

\section{Acknowledgements}

We are indebted to the participating inmates and the Gorgan prison authorities for their cooperation.

\section{Authors' contributions \\ SH processed the data, performed the analysis, and drafted the manuscript. MA provided critical feedback and was a major contributor to revising the manuscript. $H P$ and $S M$ conceived the original idea and designed the project. GR, TA, and AB conducted the study and were involved in data collection. RM and AF supervised the work. MS and NMG provided insight into the interpretation of the results. The authors read and approved the final manuscript.}

\section{Funding}

This work was supported by the Iranian Ministry of Health and Medical Education [grant number 700/1897]. Maryam Sharafkhah is funded by the National Institute for Medical Research Development (NIMAD) [grants number 982678].

\section{Availability of data and materials}

The datasets used and/or analyzed during the current study are available from the corresponding author on reasonable request.

\section{Ethics approval and consent to participate}

The Institutional Review Board of Tehran University of Medical Sciences (TUMS) approved the research protocol. All participants provided written informed consent.

\section{Consent for publication}

Not applicable.

\section{Competing interests}

The authors declare that they have no competing interests.

\section{Author details}

${ }^{1}$ Liver and Pancreatobiliary Diseases Research Center, Digestive Diseases Research Institute, Shariati Hospital, Tehran University of Medical Sciences, Tehran, Iran. ${ }^{2}$ Digestive Disease Research Center, Digestive Disease Research Institute, Shariati Hospital, Tehran University of Medical Sciences, Tehran, Iran. ${ }^{3}$ The Kirby Institute, UNSW Sydney, Sydney, NSW, Australia. ${ }^{4}$ Golestan Research Center of Gastroenterology and Hepatology, Golestan University of Medical Sciences, Gorgan, Iran. ${ }^{5}$ Cancer Research Center, Golestan University of Medical Sciences, Gorgan, Iran. ${ }^{6}$ Department of Health, Golestan State Prisons and Security and Corrective Measures Organization, Gorgan, Iran. ${ }^{7}$ Digestive Oncology Research Center, Digestive Diseases Research Institute, Shariati Hospital, Tehran University of Medical Sciences, Tehran, Iran.

Received: 4 May 2020 Accepted: 28 July 2020

Published online: 14 August 2020

\section{References}

1. Organization WH. WHO global hepatitis report 2017. 2017.

2. Falade-Nwulia O, Suarez-Cuervo C, Nelson DR, Fried MW, Segal JB, Sulkowski MS. Oral direct-acting agent therapy for hepatitis $\mathrm{c}$ virus infection: a systematic review. Ann Intern Med. 2017;166(9):637-48.

3. Kassaian N, Adibi P, Kafashaian A, Yaran M, Nokhodian Z, Shoaei P, et al. Hepatitis $C$ virus and associated risk factors among prison inmates with history of drug injection in Isfahan, Iran. Int J Prev Med. 2012;3(Suppl 1): S156-S61

4. Moradi G, Gouya M-M, Azimizan Zavareh F, Mohamadi Bolbanabad A, Darvishi S, Aghasadeghi MR, et al. Prevalence and risk factors for HBV and $\mathrm{HCV}$ in prisoners in Iran: a national bio-behavioural surveillance survey in 2015. 2018:23(6):641-9.

5. Mirminachi B, Mohammadi Z, Merat S, Neishabouri A, Sharifi AH, Alavian SH, et al. Update on the prevalence of hepatitis $C$ virus infection among iranian general population: a systematic review and meta-analysis. Hepat Mon. 2017:17(2):e42291.

6. Malekinejad M, Navadeh S, Lotfizadeh A, Rahimi-Movaghar A, Amin-Esmaeili M, Noroozi A. High hepatitis C virus prevalence among drug users in Iran: systematic review and meta-analysis of epidemiological evidence (20012012). Int J Infect Dis. 2015:40:116-30.

7. Behzadifar M, Gorji HA, Rezapour A, Bragazzi NL. Prevalence of hepatitis C virus infection among prisoners in Iran: a systematic review and metaanalysis. Harm Reduct J. 2018;15(1):24

8. Hajarizadeh B, Razavi-Shearer D, Merat S, Alavian SM, Malekzadeh R, Razavi $H$. Liver disease burden of hepatitis $C$ virus infection in Iran and the potential impact of various treatment strategies on the disease burden. Hepat Mon. 2016;16(7):e37234-e.

9. Nematollahi S, Ayubi E, Almasi-Hashiani A, Mansori K, Moradi Y, Veisani Y, et al. Prevalence of hepatitis $C$ virus infection among high-risk groups in Iran: a systematic review and meta-analysis. Public Health. 2018;161:90-8.

10. Hajarizadeh B. Generic direct acting antiviral treatment: the first step towards elimination of hepatitis C in Iran. 2017;17(1):e45788.

11. Sharafi H, Nikbin M, Alavian SH, Behnava B, Alavian SM. Efficacy and safety of generic Sofosbuvir/Ledipasvir fixed-dose combination in Iranian patients with chronic hepatitis C virus infection. 2017;17(6):e12216.

12. Merat S, Sharifi AH, Haj-Sheykholeslami A, Poustchi H, Fattahi B, NateghiBaygi A, et al. The efficacy of 12 weeks of Sofosbuvir, Daclatasvir, and Ribavirin in treating hepatitis C patients with cirrhosis, genotypes 1 and 3 . 2017; 17(1):e44564 
13. Saberi Zafarghandi MB, Jadidi M, Khalili N. Iran's activities on prevention, treatment and harm reduction of drug abuse. Int J High Risk Behav Addict. 2015;4(4):e22863-e.

14. Moradi G, Farnia M, Shokoohi M, Shahbazi M, Moazen B, Rahmani K Methadone maintenance treatment program in prisons from the perspective of medical and non-medical prison staff: a qualitative study in Iran. Int J Health Policy Manag. 2015;4(9):583-9.

15. Farhoudi B, SeyedAlinaghi S, Ataeinia B, Hosseini M, Jafari S, Alasvand R, et al. Comparison of HIV indicators after implementation of a new model for TB and HIV management in an Iranian prison. Infect Disord Drug Targets. 2019.

16. Farhoudi B, SeyedAlinaghi S, Tabarsi P, Mohraz M, Golrokhy R, Farnia M, et al. Revision and implementation of "Clinical Guideline for Tuberculosis and HIV in Prisons", Great Tehran Prison. Iran. Infect Disord Drug Targets. 2018; 18(1):72-80.

17. Seyed Alinaghi SA, Farhoudi B, Mohraz M, Alipour A, Golrokhy R, Hosseini M, et al. Adherence to antiretroviral therapy and tuberculosis treatment in a prison of Tehran. Iran. Infect Disord Drug Targets. 2016;16(3):199-203.

18. Kuncio DE, Newbern EC, Fernandez-Viña MH, Herdman B, Johnson CC, Viner KM. Comparison of risk-based hepatitis $C$ screening and the true seroprevalence in an urban prison system. J Urban Health. 2015:92(2):379-86.

19. Stockman LJ, Greer J, Holzmacher R, Dittmann B, Hoftiezer SA, Alsum LE, et al. Performance of risk-based and birth-cohort strategies for identifying hepatitis C virus infection among people entering prison, Wisconsin, 2014. Public Health Rep (Washington, DC: 1974). 2016;131(4):544-51.

20. Khodabakhshi B, Abbassi A, Fadaee F, Rabiee M. Prevalence and risk factors of HIV, hepatitis B virus and hepatitis $C$ virus infections in drug addicts among Gorgan prisoners. J Med Sci. 2007;7.

21. Alavi M, Poustchi H, Merat S, Kaveh-Ei S, Rahimi-Movaghar A, Shadloo B, et al. An intervention to improve HCV testing, linkage to care, and treatment among people who use drugs in Tehran, Iran: The ENHANCE study. Int J Drug Policy. 2019;72:99-105.

22. Morgan JR, Servidone M, Easterbrook P, Linas BP. Economic evaluation of $\mathrm{HCV}$ testing approaches in low and middle income countries. BMC Infect Dis. 2017;17(Suppl 1):697.

23. Macalino GE, Vlahov D, Sanford-Colby S, Patel S, Sabin K, Salas C, et al. Prevalence and incidence of HIV, hepatitis B virus, and hepatitis $C$ virus infections among males in Rhode Island prisons. Am J Public Health. 2004; 94(7):1218-23.

24. Morris MD, Brown B, Allen SA. Universal opt-out screening for hepatitis C virus ( $\mathrm{HCV}$ ) within correctional facilities is an effective intervention to improve public health. Int J Prison Health. 2017:13(3-4):192-9.

25. Calabrese J. Iran's war on drugs: holding the line.

26. Beckwith CG, Kurth AE, Bazerman LB, Patry EJ, Cates A, Tran L, et al. A pilot study of rapid hepatitis $C$ virus testing in the Rhode Island Department of Corrections. J Public Health (Oxford, England). 2016;38(1):130-7.

27. Shahzamani K, Sabahi F, Merat S, Sadeghizadeh M, Lashkarian HE, Rezvan H, et al. Rapid low-cost detection of hepatitis C virus RNA in HCV-infected patients by real-time RT-PCR using SYBR Green I. Arch Iran Med. 2011;14(6):396-400.

28. Bajis S, Dore GJ, Hajarizadeh B, Cunningham EB, Maher L, Grebely J. Interventions to enhance testing, linkage to care and treatment uptake for hepatitis $C$ virus infection among people who inject drugs: a systematic review. Int J Drug Policy. 2017:47:34-46.

29. Hernández D, Feaster DJ, Gooden L, Douaihy A, Mandler R, Erickson SJ, et al. Self-reported HIV and HCV screening rates and serostatus among substance abuse treatment patients. AIDS Behav. 2016;20(1):204-14.

30. Thornton L, Barry J, Long J, Allwright S, Bradley F, Parry JV. Comparison between self-reported hepatitis B, hepatitis C, and HIV antibody status and oral fluid assay results in Irish prisoners. Commun Dis Public Health. 2000; 3(4):253-5.

31. Poustchi H, Esmaili S, Mohamadkhani A, Nikmahzar A, Pourshams A, Sepanlou SG, et al. The impact of illicit drug use on spontaneous hepatitis C clearance: experience from a large cohort population study. PLoS One. 2011;6(8):e23830-e.

32. Macalino GE, Dhawan D, Rich JD. A missed opportunity: hepatitis C screening of prisoners. Am J Public Health. 2005:95(10):1739-40.

33. Bielen R, Stumo SR, Halford R, Werling K, Reic T, Stöver H, et al. Harm reduction and viral hepatitis $C$ in European prisons: a cross-sectional survey of 25 countries. Harm Reduct J. 2018;15(1):25.
34. Sharafi H, Poustchi H, Azimian F, Tamadoni B, Ramezani R, Gouya M, et al. Performance of a rapid diagnostic test for screening of hepatitis $C$ in a reallife prison setting. J Clin Virol. 2019;113.

\section{Publisher's Note}

Springer Nature remains neutral with regard to jurisdictional claims in published maps and institutional affiliations.
Ready to submit your research? Choose BMC and benefit from:

- fast, convenient online submission

- thorough peer review by experienced researchers in your field

- rapid publication on acceptance

- support for research data, including large and complex data types

- gold Open Access which fosters wider collaboration and increased citations

- maximum visibility for your research: over $100 \mathrm{M}$ website views per year

At BMC, research is always in progress.

Learn more biomedcentral.com/submissions 